\title{
Faktor-Faktor yang Berhubungan dengan Perilaku Pencegahan HIV/AIDS pada Kelompok LSL (Lelaki Seks Lelaki) Di Kota Palu
}

\author{
Factors Related to HIVIAIDS Prevention Behavior on MSM Group (Male Sex Male) in Palu \\ City
}

\author{
Septiani*1, Herawanto $^{1}$, Rasyika Nurul ${ }^{2}$, Hartiansi Sarapang ${ }^{3}$ \\ ${ }^{1}$ Program Studi Kesehatan Masyarakat, Departemen Epidemiologi, UNTAD, Kota Palu \\ ${ }^{2}$ Program Studi Kesehatan Masyarakat, Departemen Promosi Kesehatan, UNTAD, Kota Palu \\ ${ }^{3}$ Dinas Kesehatan Provinsi Sulteng, Kota Palu \\ e-mail: *septianii029@gmail.com, herawantosamad@gmail.com, rasyika.nurul@yahoo.com, hartiansi@gmail.com
}

\begin{abstract}
Abstrak
Laki-laki berhubungan seks dengan laki-laki (LSL) adalah salah satu kelompok berisiko tinggi penularan HIVIAIDS karena perilaku seksual mereka adalah anal dan seks oral. Berdasarkan data dari Dinas Kesehatan Kota Palu pada tahun 2019 bahwa 94 kasus HIV terjadi pada LSL. Tujuan dari penelitian ini adalah untuk mengetahui faktor yang berhubungan dengan perilaku pencegahan HIVIAIDS pada kelompok LSL di Kota Palu. Jenis penelitian adalah kuantitatif dengan pendekatan cross sectional. Populasi berjumlah 284 orang, setelah menggunakan rumus slovin didapatkan sampel sebanyak 74 orang yang diambil melalui teknik snawball sampling. Analisis data menggunakan univariat dan bivariat menggunakan uji chi-square dengan nilai $\alpha<0,05$. Hasil penelitian menunjukkan beberapa variabel yaitu: pengetahuan $(p=0,037)$, sikap $(p=0,005)$, dan dukungan petugas kesehatan $(p=$ 0,000 ) berhubungan dengan perilaku pencegahan HIVIAIDS pada kelompok LSL di Kota Palu. Kesimpulan: Ada hubungan antara pengetahuan, sikap, dukungan petugas kesehatan dengan perilaku pencegahan HIVIAIDS pada kelompok LSL di Kota Palu, disarankan kepada LSL untuk meningkatkan perilaku pencegahan dengan menggunakan kondom secara konsisten dan memanfaatkan layanan konseling dan tes HIV, dan petugas kesehatan dapat memberikan bantuan perawatan dan konseling tanpa stigma dan diskriminasi.
\end{abstract}

\section{Kata Kunci : HIVIAIDS, Kondom, LSL, Perilaku kesehatan}

\begin{abstract}
Men having Sex with Men (MSM) is one of the groups with high risk of HIVIAIDS transmission because their sexual behavior is anal and oral sex. Based on data from Palu City Public Health Office in 2019, 94 cases of HIV occurred in MSM. The purpose of this study was to determine the factors associated with HIVIAIDS prevention behavior on MSM group in Palu City. The type of research was quantitative with cross sectional approach. The population of 284 people, after using Slovin formula obtained sample of 74 people who were chosen through snawball sampling technique. Data analysis used univariate and bivariate using chi-square test with value of $\alpha<0.05$. The results showed that several variables, they are: knowledge $(p=0,037)$, attitude $(p=0,005)$, and support from health workers $(p=0,000)$ were associated with HIVIAIDS prevention behavior on MSM group in Palu City. Conclusions: There is a relationship between knowledge, attitudes, and support from health workers with HIVIAIDS prevention behavior on MSM group in Palu City, it is advisable for MSM to increase their preventive behavior by using condoms consistently and utilizing HIV test and counseling services, and health workers can provide care and counseling assistance without stigma and discrimination.
\end{abstract}

Keywords: HIVIAIDS, Condom, MSM, Health behavior 


\section{Pendahuluan}

Human Immunodeficiency Virus (HIV) pertama kali ditemukan di Los Angeles sekitar Tahun 1980, virus ini menyerang sistem kekebalan tubuh sehingga menurunkan kemampuannya untuk melawan infeksi lain sebelum akhirnya berkembang menjadi AIDS. HIV dapat ditularkan melalui beberapa cara, yaitu melalui hubungan seksual secara heteroseksual, homoseksual, penggunaan alat suntik (Penasun) secara bergantian, transfusi darah dan penularan dari ibu ke anak (perinatal) ${ }^{1}$. Peraturan Menteri Kesehatan RI No. 4 Tahun 2019 menyebutkan ada 8 kelompok populasi berisiko tinggi terinfeksi HIV yaitu Ibu hamil, pasien TBC, Pasien (IMS), Penjaja seks, Lelaki Seks lelaki (LSL), Transgender/Waria, Penasun, dan Warga Binaan Permasyarakatan $(\mathrm{WBP})^{2}$.

Global HIV and AIDS Statistics menyatakan sejak awal terjadi epidemi HIV/AIDS sampai Tahun 2018 tercatat lebih dari 74,9 juta orang telah didiagnosa HIV dan 32 juta diantaranya telah meninggal. Pada Tahun 2018 jumlah orang yang hidup dengan HIV diseluruh dunia mencapai 37,9 juta orang ${ }^{3}$. HIV dan AIDS diperkirakan berada di Afrika sekitar $70 \%$ dan di Asia $30 \%{ }^{4}$. CDC meperkirakan pada Tahun 2017 orang yang didiagnosa HIV di AS sebanyak 1.003.782, 765.129 kasus diantaranya adalah laki-laki dan risiko penularan terbanyak terdapat pada kelompok LSL sebanyak 550.893 orang $(72 \%)$.

Insiden HIV di Indonesia mencapai 0,19 per 1000 penduduk, insiden tersebut masih di bawah angka global (0,26 per 1000 penduduk, namun berada di atas angka rata-rata wilayah Asia Tenggara (0,08 per 1000 penduduk) ${ }^{5}$. Sejak awal ditemukan kasus HIV/AIDS di Indonesia sampai dengan Bulan Juni 2019, sudah dilaporkan sebanyak 463 (90,07\%) Kabupaten/Kota dari 498 Kabupaten/Kota di seluruh Provinsi di Indonesia yang sudah terkonfirmasi adanya kasus HIV/AIDS 6. Ditjen P2P Kemenkes RI Tahun 2017 menyebutkan, jumlah kumulatif kasus HIV di Indonesia sebanyak 48.300 kasus dan AIDS sebanyak 9.280 kasus. Gambaran jumlah kasus pada kelompok berisiko yang didiagnosa HIV positif yaitu, pada kelompok LSL sebanyak 10.628 kasus, pada kelompok WPS sebanyak 3.313 kasus, PPS (Pria Pekeria Seks) sebayak 112 kasus, Waria sebanyak 1.002 kasus, dan IDU (Injecting Drug User) sebanyak 832 kasus ${ }^{7}$.

Sulawesi Tengah termasuk salah satu Provinsi yang telah dilaporkan terkait adanya kasus HIV/AIDS. Trend kasus HIV/AIDS dari Tahun ketahun cenderung meningkat, pada Tahun 2019 dilaporkan sebanyak 369 kasus HIV dan AIDS sebanyak 152 kasus. Secara kumulatif, kasus HIV sampai dengan Tahun 2019 sebanyak 1.811 kasus, jumlah AIDS sebanyak 913 kasus dan 393 kasus diantaranya meninggal dunia. GambaranKasus HIV/AIDS berdasarkan faktor risiko pada Tahun 2019, menunjukkan bahwa jumlah kasus terbayak ada pada kolompok TB sebanyak 41 kasus, pada kelompok (lain-lain) sebanyak 39 kasus, pasangan Risti sebanyak 31 kasus, LSL sebanyak 26 kasus, Waria sebanyak 11 kasus, pelanggan PS sebanyak 7 kasus, WPS sebanyak 6 kasus, dan yang terendah pada kelompok penasun sebanyak 1 kasus $^{8}$.

Kota Palu berada diperingkat pertama dengan kasus HIV/AIDS terbanyak dari 13 Kabupaten/Kota yang ada di Provinsi Sulawesi Tengah, tercatat pada Tahun 2002 sampai Tahun 2019 jumlah kumulatif kasus HIV sebanyak 880 kasus, AIDS sebanyak 319 kasus dan 107 kasus diantaranya meninggal dunia. Pada Tahun 2019 jumlah kasus HIV sebanyak 114 kasus, AIDS sebanyak 28 kasus, dan 5 kasus diantaranya meninggal. Gambaran kasus HIV-AIDS berdasarkan populasi kunci atau faktor risiko dari Tahun 2015-2019, menunjukkan bahwa jumlah kasus terbayak pada kolompok kunci (lain-lain) sebanyak 192 kasus, (LSL) lelaki seks lelaki sebanyak 155 kasus, pelanggan sebanyak 116 kasus, WPS sebanyak 43 kasus dan waria sebanyak 28 kasus. ${ }^{9}$

Lelaki Seks Lelaki (LSL) adalah laki-laki yang terlibat dalam hubungan seksual dengan laki-laki lain. LSL dapat mencakup orang-orang yang mengidentifikasi diri sebagai gay atau 
biseksual, pria transgander yang berhubungan seks dengan laki-laki dan laki-laki yang mengidentifikasi sebagai heteroseksual, beberapa lelaki yang berhubungan seks dengan lelaki juga membentuk hubungan atau menikah dengan perempuan. LSL berpeluang lebih besar 20 kali untuk terinfeksi HIV dibandingkan dengan populasi umum. Penelitian dilakukan pada LSL di 6 kota di Amerika Serikat menunjukkan bahwa faktor risiko penularan HIV/AIDS pada LSL yaitu tidak menggunakan pelindung ketika berhubungan anal seks dan jumlah partner seks. Penelitian yang dilakukan di Oklahoma pada 252 LSL, didapatkan hasil bahwa Laki-laki yang berhubungan seks dengan laki-laki (LSL) memiliki risiko 28 kali lebih tinggi tertular HIV dibandingkan laki-laki yang berhubungan seks dengan perempuan ${ }^{10}$. Penelitian yang dilakukan di Denmark, menunjukkan bahwa $66 \%$ LSL positif HIV melakukan anal seks ${ }^{11}$.

Perilaku LSL di Kota Palu menunjukkan bahwa LSL belum sadar akan pentingnya kondom bagi pencegahan HIV/AIDS, terbukti ada LSL yang menyatakan bahwa pelicin yang digunakan saat seks anal adalah air ludah dan masih ada LSL yang belum konsisten memakai kondom. Banyak faktor yang dapat mempengaruhi perilaku kesehatan, menurut Lawrence Green (1980), yang melatarbelakangi terjadinya perilaku kesehatan dipengaruhi oleh 3 faktor, yaitu faktor pemudah (predisposing) seperti pengetahuan, sikap, kepercayaan, nilai, pengalaman, serta beberapa faktor sosial demografi seperti ekonomi, umur dan jender. Faktor pemungkin (enabling) seperti ketersediaan sarana dan prasarana. Faktor penguat (reinforcing) seperti dukungan dari lingkungan maupun dari petugas kesehatan ${ }^{12}$.

Pengetahuan merupakan dasar dalam diri seseorang untuk bertindak atau berperilaku. Jika pengetahuan baik maka perilaku akan mengikutinya, dan sebaliknya jika pengetahuan tidak baik maka perilaku akan mengarah pada tindakan-tindakan yang tidak baik. Pengetahuan yang harus diketahui oleh kelompok LSL yaitu, terkait kesehatan reproduksi khusunya pada penyakit menular HIV/AIDS. Mulai dari gejala yang dapat ditimbulkan, penularannya melalui apa saja, pengobatan yang harus dicapai ketika dinyatakan positif HIV/AIDS, dan yang utama adalah pengetahuan terkait pencegahan apa yang bisa dilakukan (seperti melakukan VCT secara rutin, menghindari perilaku seks anal tanpa pelindung, menghindari pesta seks. Penelitian yang dilakukan oleh Listina dan Baharza (2020), menyatakan ada hubungan antara pengetahuan dengan perilaku pencegahan HIV\&AIDS pada LSL (Laki-laki Seks dengan Laki-laki) dengan nilai $p=0,039(p<0,05){ }^{13}$.

Sikap dapat terwujud diawali dari pengetahuan yang dipersepsikan sebagai sesuatu hal yang baik (positif) maupun tidak baik (negatif), kemudian dinternalisasıkan dalam diri. Jika yang dipersepsikan positif, maka seseorang akan cenderung berperilaku positif. Sebaliknya jika yang dipersepsikan negatif maka sesorang akan berperilaku negatif ${ }^{14}$. Sikap yang utama yang harus dilakukan oleh kelompok bersiko LSL di Kota Palu adalah konsistensi dalam penggunaan kondom dan melakukan VCT secara rutin sebagai bentuk dari pencegahan HIV/AIDS. Penelitian yang dilakukan oleh Rahmadhani (2018), menyatakan ada hubungan antara sikap dengan perilaku GWL dalam memanfaatkan layanan konseling dan tes HIV, dengan nilai uji statistik didapatkan hasil $p$ value $0,000(\alpha>0,05){ }^{15}$.

Kualitas dan umur harapan hidup orang yg didiagnosis HIV/AIDS dipengaruhi berbagai faktor, seperti dukungan psikologis dan psikososial. Dukungan psikologis dan psikososial bisa didapatkan melalui tenaga medis atau petugas kesehatan ${ }^{16}$. Dukungan yang dilakukan petugas kesehatan Kota Palu terkait pencegahan HIV/AIDS yaitu, upaya penemuan penderita dilakukan melalui skrining HIV/AIDS terhadap darah donor, pemantauan pada kelompok kunci seperti LSL (Lelaki Seks Lelaki) wanita penjaja seks, pengguna narkoba dengan suntik, penghuni lapas atau pada kelompok beresiko rendah seperti ibu rumah tangga. Penelitian yang dilakukan Rahmadhani, dapat membuktikan adanya hubungan yang signifikan antara peran petugas kesehatan dengan 
perilaku Gay,Waria, LSL (GWL) dalam memanfaatkan layanan konseling dan tes HIV, dengan nilai uji statistic didapatkan hasil $p$-value $0,000(\alpha<0,05){ }^{15}$.

Komisi Penanggulangan Aids (KPA) Kota Palu menyebutkan pada Tahun 2011 jumlah pemetaan pada kelompok LSL sebanyak 84 orang, dan meningkat pada Tahun 2014 sebayak 284 orang. Berdasarkan studi pendahuluan yang dilakukan peneliti terhadap 9 reponden LSL, didapatkan hasil sebanyak 7 responden $(77,8 \%)$ berada pada rentan umur 20-30 tahun dan sebanyak 2 responden $(22,2 \%)$ berada pada rentan umur $<20$ tahun. Responden yang berpendidikan SMA sebanyak 6 responden $(66,7 \%)$, S1 sebanyak 2 responden $(22.2 \%)$ dan 1 responden $(11,1 \%)$ berpendidikan SMP. LSL yang sudah melakukan hubungan seksual dengan cara anal sebanyak 7 responden $(77,8 \%)$, yang belum pernah melakukan anal seks sebanyak 2 responden $(22,2 \%)$. dan semua responden menjawab sudah pernah melakukan oral seks. Perilaku pencegahan HIV/AIDS pada kelompok LSL cenderung kurang baik, sebagian besar responden menyatakan tidak selalu menggunakan kondom saat melakukan hubungan seksual dengan pasangan. Sebanyak 5 responden (55,6\%) menjawab kadang kadang, sebanyak 2 responden $(22,2 \%)$ menjawab tidak pernah, dan hanya 2 responden $(22,2 \%)$ yang menjawab selalu memakai kondom. Untuk praktik VCT sebagian besar responden sudah melakukan VCT, sebanyak 7 responden $(72,8 \%)$ telah melakukan VCT secara rutin, sebanyak 1 responden $(11.1 \%)$ menjawab jarang, dan yang belum pernah melakukan VCT sebanyak 1 responden $(11,1 \%)$. Sedangkan untuk ketersedian kondom, sebanyak 6 responden $(66,7 \%)$ menjawab dari komunitas/petugas kesehatan dan sebanyak 3 responden $(33.3 \%)$ menjawab beli sendiri.

Berdasarkan uraian latar belakang di atas, maka peneliti tertarik untuk meneliti mengenai "Faktor-faktor yang berhubungan dengan perilaku pencegahan HIV/AIDS pada kelompok LSL (Lelaki Seks Lelaki) di Kota Palu”.

\section{Metode Penelitian}

Penelitian ini adalah penelitian kuantitatif dengan pendekatan survey analitik, dengan desain Cross Sectional. Instrumen yang digunakan dalam penelitian ini adalah kuisioner yang sudah diuji reliabilitas dan validitas. Kriteria objektif dari variabel pengetahuan menggunkan skala guttman dengan memberikan 2 alternatif jawaban yaitu jawaban (ya dan tidak), yang kemudian jawaban responden di jumlah, jika jawaban responden $\geq 50 \%$ maka dikategorikan baik sedangkan jika jawaban responden $<50 \%$ maka dikategorikan kurang baik. Sedangkan untuk variabel dukungan petugas kesehatan dikategorikan mendapatkan dukungan jika jawaban responden $\geq 50 \%$ sedangkan dikategorikan kurang mendapatkan dukungan jika jawaban responden $<50 \%$ maka dikategorikan kurang baik. Kriteria objektif untuk variabel sikap menggunakan skala likert dengan memberikan 4 alternatif jawaban yaitu jawaban (sangat setuju, setuju, tidak setuju, dan sangat tidak setuju), yang kemudian jawaban responden di jumlah, jika jawaban responden $\geq 20$ maka dikategorikan baik sedangkan jika jawaban responden $<20$ maka dikategorikan kurang baik.

Penelitian ini dilakukan di Yayasan Banuata Pura Support Kota Palu, dari bulan april s/d juni 2020. Populasi penelitian sebanyak 284 orang dan setelah dihitung menggunakan rumus Slovin didapatkan sampel sebanyak 74 orang. Teknik pengambilan sampel secara snawball sampling. Analisis data yang digunakan adalah analisis univariat dan bivariat, analisis bivariat menggunakan uji chis-square (2x2) dengan $a<(0,05)$. 


\section{Hasil}

\section{A. Analisis Univariat}

Adapun analisis univariat dari penelitian ini adalah mencakup distribusi dan frekuensi dari Karakteristik responden (umur, suku bangsa, pendidikan terakhir, pekerjaan saat ini, periode menjadi LSL, peran seksual LSL, jumlah pasangan seksual, dan intensitas berhubungan seksual). Variabel independen (pengetahuan, sikap, ketersediaan kondom, dukungan petugas kesehatan dan dukungan pasangan seksual). Variabel dependen (perilaku pencegahan HIV/AIDS).

Tabel 1. Distribusi dan frekuensi karakteristik responden

\begin{tabular}{|c|c|c|}
\hline Kelompok umur & Frequency & Percent (\%) \\
\hline 16-20 Tahun & 5 & 6.8 \\
\hline 21-25 Tahun & 33 & 44,6 \\
\hline 26-30 Tahun & 24 & 32,4 \\
\hline 31-35 Tahun & 10 & 13,5 \\
\hline 36-40 Tahun & 2 & 2.7 \\
\hline Total & 75 & 100,0 \\
\hline Suku Bangsa responden & Frequency & Percent (\%) \\
\hline Kaili & 33 & 44.6 \\
\hline Jawa & 9 & 12,2 \\
\hline Bugis & 17 & 23,0 \\
\hline Lainnya & 15 & 20,3 \\
\hline Total & 74 & 100.0 \\
\hline Pendidikan terakhir & Frequency & Percent (\%) \\
\hline SD/Sederajat & 2 & 2.7 \\
\hline SMP/Sederajat & 2 & 2,7 \\
\hline SMA/Sederajat & 57 & 77,0 \\
\hline Sarjana/Universitas & 13 & 17,6 \\
\hline Total & 74 & 100,0 \\
\hline Pendidikan terakhir & Frequency & Percent (\%) \\
\hline SD/Sederajat & 2 & 2.7 \\
\hline SMP/Sederajat & 2 & 2,7 \\
\hline SMA/Sederajat & 57 & 77,0 \\
\hline Sarjana/Universitas & 13 & 17,6 \\
\hline Total & 74 & 100,0 \\
\hline Pekerjaan saat ini & Frequency & Percent (\%) \\
\hline Pelajar/Mahasiswa & 25 & 33,8 \\
\hline Wiraswasta & 37 & 50,0 \\
\hline Pegawai/Buruh & 5 & 6,8 \\
\hline Lainnya & 7 & 9,5 \\
\hline Total & 74 & 100,0 \\
\hline Periode menjadi LSL & Frequency & Percent $(\%)$ \\
\hline Kurang dari 6 bulan & 12 & 16,2 \\
\hline
\end{tabular}




\begin{tabular}{lll}
6 BLN s.d 1 tahun & 15 & 20,3 \\
1 THN s.d 3 tahun & 17 & 23, \\
Lebih dari 3 tahun & 30 & 40,5 \\
\hline Total & 74 & 100,0 \\
\hline Peran seksual LSL & Frequency & Percent $(\%)$ \\
\hline Top & 33 & 44,6 \\
Bottom & 21 & 28,4 \\
Versitile/Fleksibel & 20 & 27,0 \\
\hline Total & 74 & 100,0 \\
\hline Jumlah pasangan seksual & Frequency & Percent $(\boldsymbol{\%})$ \\
\hline Hanya 1 saja & 27 & 36,5 \\
2 s.d 3 orang & 17 & 23,0 \\
Lebih dari 3 orang & 30 & 40,5 \\
\hline Total & 74 & 100,0 \\
\hline Intensitas berhubungan & Frequency & Percent $(\%)$ \\
seksual & & \\
\hline Sekali dalam 1 bulan & 6 & 8,1 \\
2 kali dalam 1 bulan & 12 & 16,2 \\
4 kali dalam 1 bulan & 21 & 28,4 \\
8 kali dalam 1 bulan & 21 & 28,4 \\
Lainnya & 14 & 81,9 \\
\hline Total & 74 & 100,0 \\
\hline Sum & &
\end{tabular}

Sumber: Data Primer, 2020

Berdasarkan tabel di atas menunjukkan bahwa dari 74 responden dapat diketahui sebagian besar responden berusia pada rentan umur 21-25 tahun yaitu sebanyak 33 responden $(44,6 \%)$, dan distribusi umur terendah pada rentan umur 36-40 tahun yaitu sebanyak 2 responden (2,7\%). Sebagian besar responden dari Suku Kaili yaitu sebanyak 33 responden $(44,6 \%)$, dan terendah pada Suku Jawa sebanyak 9 responden (12,2\%). Sebagian besar responden berpendidikan terakhir yaitu pada pendidikan SMA/Sederajat sebanyak 57 responden $(77,0 \%)$, dan terendah yaitu pada pendidikan SD dan SMP/Sederajat sebanyak 4 responden $(5,4 \%)$. Sebagian besar responden memiliki pekerjaan wiraswasta sebanyak 37 responden $(50,0 \%)$, dan distirbusi terendah, pada pekerjaan pegawai/buruh yaitu sebanyak 5 responden $(6,8 \%)$. Sebagian besar responden sudah menjadi LSL lebih dari 3 tahun yaitu sebanyak 30 responden (40,5\%), dan yang terendah, pada waktu kurang dari 6 bulan yaitu sebanyak 12 responden $(16,2 \%)$. Sebagian besar responden memiliki peran seksual top sebanyak 33 orang $(44,6 \%)$, dan yang terendah pada peran seksual fleksibel yaitu sebanyak 20 responden $(27,0 \%)$. Sebagian besar responden memiliki pasangan seksual lebih dari 3 orang yaitu sebanyak 30 responden $(40,5 \%)$, dan yang terendah pada jumlah pasangan seksual 2 sampai dengan 3 orang yaitu sebanyak 17 responden (23,0\%). Sebagian besar melakukan hubungan seksual 4 kali dan 8 kali dalam 1 bulan yaitu sebanyak 42 responden $(56,8 \%)$, dan yang terendah pada intensistas berhubungan seksual sekali dalam sebulan yaitu sebanyak 6 responden $(8,1 \%)$. 
Tabel 2. Distribusi frekuensi variabel independen dan dependen

\begin{tabular}{lll}
\hline Pengetahuan & Frequency & Percent $(\%)$ \\
\hline Baik & 66 & 89,2 \\
Kurang baik & 8 & 10,8 \\
\hline Total & 74 & 100,0 \\
\hline Sikap & Frequency & Percent $(\%)$ \\
\hline Baik & 66 & 89,2 \\
Kurang baik & 8 & 10,8 \\
\hline Total & 74 & 100,0 \\
\hline Dukungan petugas kesehatan & Frequency & Percent $(\%)$ \\
\hline Mendapatkan dukungan & 66 & 89,2 \\
Kurang mendapatkan dukungan & 8 & 10,8 \\
\hline Total & 74 & 100,0 \\
\hline Perilaku pencegahan HIV/AIDS & Frequency & Percent $(\%)$ \\
\hline Baik & 60 & 81,1 \\
Tidak baik & 14 & 18,9 \\
\hline Total & 74 & 100,0 \\
\hline Sumber: Data Primer, 2020 & &
\end{tabular}

Sumber: Data Primer, 2020

Berdasarkan tabel di atas menunjukkan bahwa dari 74 responden dapat diketahui sebagian besar responden memiliki pengetahuan baik yaitu sebanyak 66 responden $(89,2 \%)$, sedangkan pada pengetahuan kurang baik yaitu sebanyak 8 responden (10,8\%). Sebagian besar responden memiliki sikap baik yaitu sebanyak 66 orang $(89,2 \%)$, sedangkan pada sikap kurang baik yaitu sebanyak 8 orang $(10,8 \%)$. Sebagian besar responden mendapatkan dukungan dari petugas kesehatan yaitu sebanyak 66 responden $(89,2 \%)$, sedangkan pada responden yang kurang mendapatkan dukungan dari petugas kesehatan yaitu sebanyak 8 responden $(10,8 \%)$. Sebagian besar responden memiliki perilaku pencegahan HIV/AIDS yang baik yaitu sebanyak 60 responden $(81,1 \%)$, sedangkan pada responden memiliki perilaku pencegahan HIV/AIDS yang tidak baik yaitu sebanyak 14 responden(18,9\%).

\section{B. Analisis Bivariat}

Adapun analisis bivariat dari penelitian ini adalah mencakup hubungan antara variabel independen seperti pengetahuan, sikap, ketersediaan kondom, dukungan petugas kesehatan dan dukungan pasangan seksual dengan variabel dependen yaitu perilaku pencegahan HIV/AIDS. 
Tabel 3. Hubungan variabel indenpenden dan variabel dependen

\begin{tabular}{|c|c|c|c|c|c|c|c|}
\hline \multirow{3}{*}{ Pengetahuan } & \multicolumn{4}{|c|}{$\begin{array}{c}\text { Perilaku pencegahan } \\
\text { HIV/AIDS }\end{array}$} & \multirow{2}{*}{\multicolumn{2}{|c|}{ Total }} & \multirow{3}{*}{$\rho$} \\
\hline & \multicolumn{2}{|c|}{ Baik } & \multicolumn{2}{|c|}{ Tidak baik } & & & \\
\hline & $\mathbf{n}$ & $\%$ & $\mathbf{N}$ & $\%$ & $\mathbf{N}$ & $\%$ & \\
\hline Baik & 56 & 75,7 & 10 & 13,5 & 66 & 89,2 & \multirow{3}{*}{0,037} \\
\hline Kurang baik & 4 & 5,4 & 4 & 5,4 & 8 & 10,8 & \\
\hline Total & 59 & 79,7 & 14 & 20.3 & 74 & 100 & \\
\hline \multirow{3}{*}{ Sikap } & \multicolumn{4}{|c|}{$\begin{array}{c}\text { Perilaku pencegahan } \\
\text { HIV/AIDS }\end{array}$} & \multirow{2}{*}{\multicolumn{2}{|c|}{ Total }} & \multirow[t]{3}{*}{$\rho$} \\
\hline & \multicolumn{2}{|c|}{ Baik } & \multicolumn{2}{|c|}{ Tidak baik } & & & \\
\hline & $\mathbf{n}$ & $\%$ & $\mathbf{N}$ & $\%$ & $\mathbf{N}$ & $\%$ & \\
\hline Baik & 57 & 77,0 & 9 & 12,2 & 66 & 89,2 & \multirow{3}{*}{0,005} \\
\hline Kurang baik & 3 & 4,1 & 5 & 62,5 & 8 & 10,8 & \\
\hline Total & 60 & 81,1 & 14 & $18.9 \%$ & 74 & 100 & \\
\hline \multirow{3}{*}{ Dukungan petugas kesehatan } & \multicolumn{4}{|c|}{$\begin{array}{c}\text { Perilaku pencegahan } \\
\text { HIV/AIDS }\end{array}$} & \multirow{2}{*}{\multicolumn{2}{|c|}{ Total }} & \multirow[t]{3}{*}{$\boldsymbol{\rho}$} \\
\hline & \multicolumn{2}{|c|}{ Baik } & \multicolumn{2}{|c|}{ Tidak baik } & & & \\
\hline & $\mathbf{n}$ & $\%$ & $\mathbf{N}$ & $\%$ & $\mathbf{N}$ & $\%$ & \\
\hline Mendapatkan dukungan & 59 & 79,7 & 7 & 9,5 & 66 & 89,2 & \multirow{3}{*}{0,000} \\
\hline Kurang mendapatkan dukungan & 1 & 1,4 & 7 & 9,5 & 8 & 10,8 & \\
\hline Total & 60 & 81,1 & 14 & 18,9 & 74 & 100 & \\
\hline
\end{tabular}

Sumber: Data Primer, 2020

Hasil penelitian yang dilakukan dari 66 responden $(89,2 \%)$ yang memiliki pengetahuan yang baik, diantaranya sebanyak 56 responden $(75,7 \%)$ memiliki perilaku pencegahan HIV/AIDS yang baik. Sedangkan responden yang tidak memiliki perilaku pencegahan HIV/AIDS yang tidak baik yaitu sebanyak 10 responden (13,5\%). Sedangkan dari 8 responden (10.8\%) yang memiliki pengetahuan kurang baik, memiliki nilai yang sama antara perilaku pencegahan HIV/AIDS yang tidak baik ataupun perilaku pencegahan HIV yang baik yaitu sebanyak 4 responden $(5,4 \%)$. Hasil analisis menggunakan uji Chi-Square yang dilakukan terhadap faktor-faktor yang berhubungan dengan perilaku pencegahan HIV/AIDS pada kelompok LSL di Kota Palu dari segi pengetahuan, didapatkan hasil $\rho=0,037(a<0,05)$ sehingga Ho ditolak, artinya bahwa ada hubungan pengetahuan dengan perilaku pencegahan HIV/AIDS pada kelompok LSL di Kota Palu.

Hasil penelitian diketahui bahwa, dari 66 responden $(89,2 \%)$ yang memiliki sikap baik lebih banyak yang memiliki perilaku pencegahan HIV/AIDS yang baik yaitu sebanyak 57 responden $(77,0 \%)$, dibanding responden yang tidak memiliki perilaku pencegahan HIV/AIDS sebanyak 9 responden (12,2\%). Sedangkan dari 8 responden $(10.8 \%)$ yang memiliki sikap kurang baik, lebih banyak yang tidak memiliki perilaku pencegahan HIV/AIDS yang tidak baik yaitu sebanyak 5 responden $(6,8 \%)$, dibanding dengan responden yang memiliki perilaku pencegahan yang baik yaitu sebanyak 3 responden $(4,1 \%)$. Hasil analisis menggunakan uji chi square yang dilakukan terhadap faktor-faktor yang berhubungan dengan perilaku pencegahan 
HIV/AIDS pada kelompok LSL di Kota Palu dari segi sikap, didapatkan hasil $\rho=0,005(a<0,05)$ Sehingga Ho ditolak, artinya bahwa ada hubungan pengetahuan dengan perilaku pencegahan HIV/AIDS.

Hasil penelitian diketahui bahwa, dari 66 responden $(89,2 \%)$ yang mendapatkan dukungan dari petugas kesehatan, lebih banyak yang memiliki perilaku pencegahan HIV/AIDS yang baik yaitu sebanyak 59 responden $(79,7 \%)$. Dibanding responden yang tidak memiliki perilaku pencegahan yang baik yaitu sebanyak 7 responden $(9,5 \%)$. Sedangkan dari 8 responden $(10,8 \%)$ yang kurang mendapatkan dukungan dari petugas kesehatan, lebih banyak yang tidak memiliki perilaku pencegahan HIV/AIDS yang tidak baik yaitu sebanyak 7 responden $(9,5 \%)$. Dibanding responden yang memiliki perilaku pencegahan yang baik yaitu hanyak 1 responden $(1,4 \%)$. Hasil analisis menggunakan uji Chi-Square yang dilakukan terhadap faktor-faktor yang berhubungan dengan perilaku pencegahan HIV/AIDS pada kelompok LSL di Kota Palu, didapatkan hasil $p=0,000(a<0,05)$ sehingga Ho ditolak, artinya bahwa ada hubungan dukungan petugas kesehatan dengan perilaku pencegahan HIV/AIDS pada kelompok LSL di Kota Palu.

\section{Pembahasan}

Pengetahuan adalah suatu hasil dari rasa keingintahuan melalui proses sensoris, terutama pada mata dan telinga terhadap objek tertentu ${ }^{17}$. Pengetahuan merupakan domain yang sangat penting dalam membentuk perilaku seseorang ${ }^{18}$. Pengetahuan HIV merupakan kemampuan yang dimiliki responden dalam menjawab pertanyaan tentang HIV meliputi pengertian, gejala, tandatanda, cara penularan, cara pencegahan, dan cara deteksi HIV ${ }^{19}$. Teori Lawrence Green menyatakan bahwa perilaku kesehatan dapat dipengaruhi oleh pengetahuan (faktor predisposisi). Menurut Notoatmodjo, Apabila penerimaan perilaku baru atau adopsi perilaku didasari oleh pengetahuan, maka apa yang dipelajari antara lain perilaku tersebut akan bersifat langgeng, sebaliknya apabila perilaku itu tidak didasari oleh pengetahuan maka tidak akan berlangsung lama. Hal ini berarti jika semakin baik pengetahuan responden mengenai HIV/AIDS, maka mempengaruhi tindakan untuk selalu menggunakan kondom saat berhubungan seks ${ }^{20}$.

Berdasarkan hasil penelitian yang dilakukan pada tabel 3 menunjukkan bahwa dari 74 responden (100\%) lebih banyak yang memiliki pengetahuan yang baik yaitu sebanyak 66 responden $(89,2 \%)$, sedangkan responden yang memiliki pengetahuan yang kurang baik yaitu sebanyak 8 responden $(10,8 \%)$. Sebagian besar responden telah memiliki pengetahuan yang baik terkait pengertian HIV/AIDS sampai dengan pencegahannya, ini dikarenakan responden sudah sering mendapatkan penyuluhan atau konseling dari Yayasan Banuata Pura Support, petugas kesehatan maupun melalui media online. Bukti lain juga menyatakan bahwa sebagian besar responden menjawab bahwa yang merupakan peningkatan terhadapa risiko terkena HIV dengan melakukan seks bebas tanpa menggunakan kondom dan gejala HIV dapat terlihatn atau dirasakan membutuhkan waktu yang lama, karena ketika respoden mulai terpapar virus akan terliat sehat. Namun hal ini tidak menutup kemungkinan bahwa masih ada responden yang belum mengetahui terkait HIV, terbukti masih ada responden yang menjawab bahwa virus HIV tidak terdapat didalam darah dan menganggap bahwa HIV dapat sembuh sempurna. Hal ini bisa disebabkan karena faktor usia, pendidikan, keterbatasan informasi, ataupun pengalaman dari LSL.

Umur merupakan keadaan yang menunjukkan lamanya hidup seseorang yang biasanya dihitung sejak hari lahirnya yang dinyatakan dalam tahun. Berdasarakan hasil analisis univariat dari 74 responden, distribusi responden menurut kelompok umur yang tertinggi adalah pada kelompok umur 21-25 tahun yaitu sebanyak 33 responden (44,6\%), sedangkan distribusi kelompok umur yang terendah ada pada kelompok umur 36-40 tahun yaitu sebanyak 2 responden $(2,7 \%)$. Hasil 
penelitian yang dilakukan di Nigeria pada 287 partisispan, menyatakan bahwa umur berpengaruh pada pengetahuan dalam memanfaatkan layanan VCT pada masyarakat metropolis Sagamu Nigeria. Dengan bertambahnya umur seseorang akan terjadi perubahan pada aspek fisik dan psikologis (mental), yang akan mempengaruhi taraf berpikir seseorang menjadi lebih matang, hal tersebut pada akhirnya akan mempengaruhi pola pikir seseorang untuk berperilaku kesehatan yang baik ${ }^{21}$.

Tingkat pendidikan merupakan jenjang pendidikan yang dimiliki oleh responden yang dikategorikan menjadi pendidikan dasar awal, menengah dan tinggi. Berdasarakan hasil analisis univariat dari 74 responden, distribusi responden menurut pendidikan terakhir yang tertinggi adalah pada pendidikan SMA yaitu sebanyak 57 responden (77,0\%), sedangkan distribusi pendidikan terendah ada pada pendidikan SD dan SMP yaitu sebanyak 4 responden $(5,4 \%)$. Hasil penelitian yang dilakukan di Amerika Serikat dan Afrika Selatan pada 439 reponden LSL, didapatkan hasil rata-rata responden di kedua kelompok hanya kehilangan 2 dari 18 pertanyaan, baik LSL di AS ataupun di Afrika Selatan, LSL dengan pendidikan kurang dari sekolah menengah memiliki pengetahuan HIV/AIDS yang jauh lebih rendah dibanding LSL yang memiliki tingkat pendidikan yang tinggi. Hal ini juga sejalan dengan sejumlah besar penelitian di seluruh dunia yang menunjukkan bahwa seiring meningkatnya tingkat pendidikan, maka demikian juga pengetahuan tentang pencegahan dan penularan HIV/AIDS. Pendidikan SD dan SMP sederajat merupakan tingkat pendidikan dasar awal, pada tingkat ini seseorang belum mampu memahami informasi yang diberikan mengenai penyakit HIV/AIDS. Pendidikan akan mempengaruhi daya serap seseorang terhadap informasi yang diterimanya yang kemudian dapat membentuk sebuah perilaku yang baik ataupun buruk 22 .

Keterbatasan informasi juga menjadi faktor yang mempengaruhi pengetahuan dalam memanfaatan layanan kesehatan. Penelitian yang sejalan dilakukan di Ethiopia pada 14 informan, yang menunjukkan bahwa peningkatan jumlah kasus HIV dan AIDS ini dihubungkan dengan minimnya tingkat pencegahan dari para pelaku seks, misalnya keterbatasan informasi yang didapat seputar tindakan pencegahan HIV dan AIDS (khususnya bagi LSL, mengingat stigma yang melekat pada mereka sebagai kelompok yang agak berbeda dari masyarakat pada umumnya) hal inilah yang membuat LSL malu untuk mencari informasi atau melakukan VCT ${ }^{23}$.

Hasil penelitian yang dilakukan, dari 66 responden $(89,2 \%)$ yang memiliki pengetahuan yang baik, lebih banyak yang memiliki perilaku pencegahan HIV/AIDS yang baik yaitu sebanyak 56 responden $(75,7 \%)$. Dibanding responden yang tidak memiliki perilaku pencegahan HIV/AIDS yang tidak baik yaitu sebanyak 10 responden (13,5\%). Sedangkan dari 8 responden $(10.8 \%)$ yang memiliki pengetahuan yang kurang baik, memiliki nilai yang sama antara perilaku pencegahan HIV/AIDS yang tidak baik ataupun perilaku pencegahan HIV yang baik yaitu sebanyak 4 responden $(5,4 \%)$. Sehingga hasil penelitian di atas menunjukkan bahwa responden yang memiliki tingkat pengetahuannya baik cenderung untuk melakukan perilaku pencegahan HIV/AIDS yang baik dibandingkan responden yang memiliki tingkat pengetahuan kurang baik. Hasil analisis menggunakan uji Chi-Square yang dilakukan terhadap faktor-faktor yang berhubungan dengan perilaku pencegahan HIV/AIDS pada kelompok LSL di Kota Palu dari segi pengetahuan, didapatkan hasil $\rho=0,037(a<0,05)$ sehingga Ho ditolak, artinya bahwa ada hubungan pengetahuan dengan perilaku pencegahan HIV/AIDS pada kelompok LSL di Kota Palu.

Hasil di atas sejalan dengan penelitian yang dilakukan di Kota Bandar Lampung, menyatakan ada hubungan antara pengetahuan dengan perilaku pencegahan HIV\&AIDS pada LSL (Laki-laki Seks dengan Laki-laki), dengan nilai $p=0,039(a<0,05)$. Pengetahuan merupakan dasar dalam diri seseorang untuk bertindak atau berperilaku jika pengetahuan baik maka perilaku akan mengikutinya sebaliknya jika pengetahuan tidak baik maka perilaku akan mengarah pada tindakan- 
tindakan yang tidak baik pula ${ }^{13}$. Penelitian lain yang dilakukan di Afrika, menyatakan bahwa rendahnya pengetahuan mengenai HIV/AIDS dapat mempengaruhi keputusan melakukan perilaku pencegahan HIV seperti rutin melakukan VCT. Seseorang yang memiliki pengetahuan tentang HIV 3,69 kali lebih mungkin untuk memanfaatkan layanan VCT dibandingkan dengan mereka yang tidak memiliki pengetahuan tentang HIV. Keadaan tersebut memperlihatkan bahwa pengetahuan memegang peranan yang penting dalam pemanfaatan layanan konseling dan tes HIV. Secara statistik bermakna terdapat hubungan pengetahuan dengan perilaku pemanfaatan layanan konseling dan tes HIV dengan nilai statistik $p=0,008(a<0,05)^{24}$.

Hasil penelitian yang mirip dilakukan di India, yang menyatakan bahwa orang yang memiliki pengetahuan tentang kebijakan AIDS lebih cenderung menggunakan kondom secara konsisten ${ }^{25}$. Hal ini adalah sesuatu yang wajar karena mereka yang pengetahuannya lebih tinggi dapat mengerti manfaat kondom secara konsisten. Mereka yang memiliki pengetahuan tentang kebijakan AIDS seringkali mendapatkan wawasan yang lebih baik tentang gejala penyakit HIV, tahu lebih banyak tentang ketersediaan kondom gratis dan menggunakan informasi ini secara lebih efektif untuk mengakses layanan kesehatan ${ }^{26}$.

Sikap merupakan Sikap adalah respon tertutup seseorang terhadap stimulus atau objek tertentu, yang sudah melibatkan faktor pendapat dan emosi yang bersangkutan senang dan tidak senang, setuju dan tidak setuju, baik dan tidak baik dan sebagainya ${ }^{27}$. LSL yang memiliki sikap yang positif terhadap perilaku pencegahan HIV/AIDS cenderung berperilaku yang konsisten terhadap perilaku pecegahan HIV seperti pemakain kondom yang konsisten dan rutin ke layanan kesehatan untuk melakukan konseling dan tes HIV ${ }^{28}$

Penelitian yang dilakukan di Kota Semarang, sikap reponden terhadap HIV yaitu pandangan dari responden mengenai HIV meliputi pengertian, cara pencegahan HIV, cara deteksi HIV, dan kelompok berisiko HIV. Sikap responden dengan kategori baik yaitu responden yang memiliki pandangan positif bahwa tes HIV bermanfaat untuk mengetahui status HIV pada responden dan berguna untuk mencegah terjadinya penularan ke orang lain. Responden yang memiliki sikap yang baik tentang hal-hal tersebut lebih memungkinkan untuk melakukan tes HIV daripada responden dengan sikap yang kurang baik. Hasil penelitian menunjukkan bahwa sebagian besar responden sangat setuju dengan pernyataan tentang tes HIV. Hasil tersebut menunjukkan bahwa responden mengetahui tentang tes HIV yang meliputi manfaat, tujuan, dan dampak ${ }^{29}$.

Berdasarkan hasil penelitian yang dilakukan pada tabel 3 menunjukkan bahwa dari 74 responden (100\%) lebih banyak yang memiliki sikap yang baik yaitu sebanyak 66 orang $(89,2 \%)$ sedangkan responden yang memiliki sikap kurang baik yaitu sebanyak 8 orang (10,8\%). Dari hasil penelitian di atas, sebagian besar responden telah memiliki sikap yang baik, hal ini dibuktikan dengan pandangan responden yang positif mengenai VCT dapat mencegah penularan HIV ke orang lain, serta responden sangat setuju bahwa berganti-ganti pasangan dapat meningkatkan risiko penularan HIV/AIDS. Namun hal ini tidak menutup kemungkinan bahwa masih ada responden yang memiliki sikap kurang baik, terbukti dari pernyataan responden yang sangat setuju dengan perilaku merokok, anal seks, gonta-ganti pasangan, mabuk-mabukkan dan menggunakan narkoba adalah gaya hidup jaman sekarang. Hal ini bisa disebabkan karena lingkungan sekitar responden, pengetahuan yang di miliki responden, serta kurangnya dukungan petugas kesehatan, dari pasangan ataupun keluarga.

Asia Pacific Coalition on Male Sexual Health dalam Wardhani,dkk ${ }^{30}$, menyatakan pada usia remaja akhir banyak pengalaman yang muncul mengenai perilaku seksual, hal itu dikarenakan rasa ingin tahu dan pengaruh lingkungan. LSL banyak ditemukan di kalangan muda dan pelajar atau mahasiswa karena pada usia muda tersebut mereka lebih sering bertemu di klub malam, karaoke, 
sauna, tempat seks komersial, kencan melalui internet, dan tempat-tempat seperti kolam renang, tempat olahraga dan fitness, maupun toilet. Usia remaja memiliki kecenderungan rasa ingin tahu yang lebih sehingga ingin mencoba hal baru, pengaruh lingkungan yang kurang baik dan pengalaman masa lalu (terkait perilaku seks menyimpang) menyebabkan seorang terjerumus pada perilaku seksual yang menyimpang.

Penelitian yang dilakukan di Bandar Lampung, sikap yang negatif terhadap perilaku pencegahan HIV\&AIDS berkaitan dengan pengetahuan yang didapatkan LSL. Pengetahuan merupakan dasar seseorang untuk bersikap, LSL dengan pengetahuan baik akan mampu bersikap positif karena ia tahu dampak dan manfaat dari sebuah perilaku, setelah tahu maka ia akan bersikap menerima saran-saran pencegahan yang kemudian sikap tersebut akan berwujud perilaku pencegahan yang baik sehingga upaya pencegahan HIV\&AIDS pada LSL dilakukan dengan penuh kesadaran dan berkelanjutan tanpa adanya paksaan. Selain pengetahuan, tuntutan ekonomi juga menjadi faktor pendorong sikap negatif para LSL, tidak adanya keterampilan yang dimiliki oleh sebagian besar responden menjadikan mereka tidak mampu berkarya dan hanya menghabiskan waktu untuk sekedar bermain sehingga banyak waktu mereka yang digunakan untuk kegiatankegiatan negatif ${ }^{13}$.

Dukungan yang diberikan petugas kesehatan sangat berpengaruh terhadap sikap LSL dalam melakukan perilaku pencegahan HIV/AIDS. Dukungan berupa informasi yang baik dapat bepengaruh positif kepada sikap yang akan LSL ambil. Penelitian yang sejalan dilakukan di Malawi, dimana kelompok LSL beranggapan bahwa pemanfaatan layanan kesehatan dapat mencegah penularan HIV/AIDS. Hal ini disebabkan karena dukungan yang diberikan petugas kesehatan berupa informasi ataupun perawatan. Petugas kesehatan yang ramah, tidak menghakimi, tidak diskriminatif, dan menghormati hak LSL merupakan salah satu faktor yang mempengaruhi sikap LSL untuk memanfaatkan layanan kesehatan ${ }^{31}$.

Dari hasil penelitian diketahui bahwa, dari 66 responden $(89,2 \%)$ yang memiliki sikap baik lebih banyak yang memiliki perilaku pencegahan HIV/AIDS yang baik yaitu sebanyak 57 responden $(77,0 \%)$, dibanding responden yang tidak memiliki perilaku pencegahan HIV/AIDS sebanyak 9 responden (12,2\%). Sedangkan dari 8 responden (10.8\%) yang memiliki sikap kurang baik, lebih banyak yang tidak memiliki perilaku pencegahan HIV/AIDS yang tidak baik yaitu sebanyak 5 responden $(6,8 \%)$, dibanding dengan responden yang memiliki perilaku pencegahan yang baik yaitu sebanyak 3 responden $(4,1 \%)$. Sehingga hasil penelitian di atas menunjukkan bahwa responden yang memiliki sikap baik cenderung untuk melakukan perilaku pencegahan HIV/AIDS yang baik dibandingkan responden yang memiliki sikap kurang baik. Hasil analisis yang dilakukan terhadap faktor-faktor yang berhubungan dengan perilaku pencegahan HIV/AIDS pada kelompok LSL di Kota Palu dari segi sikap, didapatkan hasil $\rho=0,005(a<0,05)$ sehingga Ho ditolak, artinya bahwa ada hubungan pengetahuan dengan perilaku pencegahan HIV/AIDS.

Hal ini sejalan dengan penelitian yang dilakukan di Kota Jambi, didapatkan hasil uji statistic dengan nilai $p$-value $0,000(a>0,05)$ yang berarti terdapat hubungan yang signifikan antara sikap dengan perilaku pencegahan HIV/AIDS pada GWL dalam memanfaatkan layanan konseling dan tes HIV di Kota jambi. Hasil analisis menunjukkan nilai Odds Rasio sebesar 17,371 yang berarti GWL yang memiliki sikap positif terhadap konseling dan tes HIV akan memanfaatkan layanan konseling dan tes HIV sebesar 17 kali dibandingkan dengan GWL yang memiliki sikap negatif terhadap konseling dan tes HIV. GWL yang memiliki sikap negatif lebih sedikit yang tidak memanfaatkan layanan konseling dan tes HIV, Sebaliknya GWL yang memiliki sikap positif lebih banyak yang memanfaatkan layanan konseling dan tes HIV. 
Penelitian yang sejalan juga dilakukan di Nigeria didapatkan risk estimate dengan nilai RP 5,93 (RP>1) dengan 95\% CI, pada kelompok responden dengan sikap yang kurang mendukung memiliki kemungkinan 5,93 kali lebih besar untuk tidak melakukan tes HIV daripada kelompok responden dengan sikap yang mendukung. Secara statistik juga bermakna terdapat hubungan yang signifikan sikap dengan perilaku pencegahan HIV/AIDS yaitu dengan nilai uji statistic diperoleh $p$ value 0,000 $(\alpha>0,05)$. Variabel usia merupakan faktor risiko dari praktik tes HIV dan secara statistik terdapat hubungan yang bermakna ${ }^{21}$.

Petugas kesehatan dapat mempengaruhi masyarakat dalam memanfaatkan pelayanan kesehatan, pengaruh tersebut dapat berupa dukungan emosional yaitu mencakup ungkapan empati, kepedulian dan perhatian terhadap kelompok LSL. Dukungan informatif yaitu mencakup pemberian nasehat, petunjuk-petunjuk, saran-saran kepada kelompok LSL. Dukungan instrumental yaitu penyediaan sarana dan mempermudah tujuan yang ingin dicapai kelompok LSL. Dukungan penghargaan berupa ungkapan hormat (penghargaan) positif, dorongan maju, pemberian penghargaan atas usaha yang telah dilakukan kelompok LSL untuk mencegah penularan HIV/AIDS 32 .

Berdasarkan hasil penelitian yang dilakukan pada tabel 3 menunjukkan bahwa dari 74 responden lebih banyak yang mendapatkan dukungan dari petugas kesehatan yaitu sebanyak 66 responden $(89,2 \%)$ sedangkan responden yang kurang mendapatkan dukungan dari petugas kesehatan yaitu sebanyak 8 responden $(10,8 \%)$. Hal ini disebabkan sebagian besar responden sudah terjangkau oleh Yayasan Banuata Pura Support sehingga petugas kesehatan ataupun Yayasan tidak kesulitan untuk memberikan dukungan. Hal ini dibuktikan dengan jawaban responden yang menyatakan, petugas kesehatan memberikan dukungan dengan memberikan brosur atau melakukan kegiatan penyuluhan kepada kelompok kunci, memberikan dukungan berupa informasi tentang pentingnya menggunakan kondom saat melakukan hubungan seksual, memberikan dukungan berupa rasa nyaman non dikriminasi dan memberikan pujian ketika LSL melakukan perilaku pencegahan HIV yang baik. Namun dukungan petugas kesehatan belum menyuluruh sampai kepada kelompok LSL, hal ini terbukti bahwa masi ada responden yang merasa tidak nyaman ketika ke pelayanan kesehatan, serta responden juga menyatakan belum pernah mengikuti penyuluhan kesehatan yang dilaksanakan oleh petugas kesehatan dan sebagaian besar responden menyatakan bahwa kondom yang dibagikan tidak mencukupi kebutuhan. Hal ini bisa disebabkan karena kelompok LSL takut ataupun malu jika mendapat penolakan, stigma yang buruk, dan diskriminasi dari petugas kesehatan.

Penelitian yang dilakukan di lima Rumah sakit Kolkata, India pada 250 responden, sebagian besar responden merasa nyaman untuk melakukan VCT karena sikap konselor yang tidak memberi stigma dan diskriminasi terhadap LSL. Kondisi tersebut membuat responden menjadi mudah akrab terhadap petugas layanan kesehatan. Petugas kesehatan yang dapat membuka diri dan menerima LSL dengan baik tanpa ada dikriminasi ataupun stigma yang buruk membuat kelompok rentan HIV tidak merasa takut dan malu ketika ingin memanfaatkan pelayanan kesehatan ${ }^{33}$.

Penelitian yang mirip dilakukan di 4 Kota di Ghana yaitu Accra/Tema, Kumasi, Cape Coast/Takoradi, dan Koforidua, kepada 1,382 LSL yang tersebar di 4 kota, 493 LSL dari Kota Acra/Tema, Kota Cape Coast/Takoradi sebanyak 397 LSL, 331 LSL dari Kota Kumasi, dan 161 LSL dari Kota Koforidua. Didapatkan hasil bahwa diskriminasi biasa terjadi di kalangan LSL dengan presentase 6,2\%-30,6\% ditolak layanan kesehatan, 29,0\%-48,9\% mengalami kekerasan verbal/simbolis, 2,8\%-12,8\% mengalami kekerasan fisik, 12,3\%-30,0\% mengalami kekerasan seksual karena seksualitas. Lelaki Seks Lelaki yang mengalami stigma dan diskriminasi dapat mempengaruhi masalah kesehatan baik segi psikis maupun fisik seperti perasaan cemas, takut, 
frustrasi, depresi, stres, rasa malu, penolakan, isolasi sendiri serta akses terbatas ke perawatan dan layanan kesehatan. Sehingga hal ini bisa menyebabkan kurangnya pemanfaatan layananan kesehatan bagi para ODHA dan kelompok kunci lainnya yang kemudian berimbas kepada tingginya kasus baru HIV/AIDS karena keterlambatan tingkat pengungkapan kasus HIV ${ }^{34}$.

Tidak menutup kemungkinan masih ada sikap yang tidak menguntungkan di antara orangorang profesional kesehatan yang memberikan stigma yang buruk dan diskriminasi kepada ODHA maupun kelompok rentan. Penelitian yang sejalan dilakukan di Shiraz kepada 575 responden penyedia layanan kesehatan rumah sakit umum dan swasta. Menurut hasil penelitian ini, 46,2\% petugas kesehatan memilih untuk tidak memberikan layanan kepada para pelacur dan Lelaki Seks Lelaki (LSL). Ketakutan akan kontaminasi dan sikap sosial adalah hambatan utama untuk menangani pasien dan memberikan layanan kepada mereka. Oleh karena itu, tampaknya menciptakan pengetahuan yang efektif tentang penularan dan memperbaiki keyakinan sosial budaya penyedia layanan kesehatan adalah dua strategi utama untuk mengatasi masalah ini ${ }^{35}$.

Penelitian yang juga sejalan dilakukan di Iran kepada 350 petugas kesehatan yang melayani ODHA dan kelompok rentan lainnya, didapatkan hasil dengan presentase 20,60\% responden setuju bahwa mereka memilih untuk tidak memberikan layanan kepada Pria yang Berhubungan Seks dengan Pria (LSL). Kurangnya pengetahuan terkait jalur penularan HIV menjadi salah satu hambatan petugas layanan kesehatan dalam berkomunikasi dan memberikan perawatan kepada mereka, serta peningkatan insidensi dan prevalensi HIV telah membuat tenaga kesehatan khawatir jika ingin berkomunikasi atau melakukan perawatan kepada mereka ${ }^{36}$.

Dari hasil penelitian diketahui bahwa, dari 66 responden $(89,2 \%)$ yang mendapatkan dukungan dari petugas kesehatan, lebih banyak yang memiliki perilaku pencegahan HIV/AIDS yang baik yaitu sebanyak 59 responden $(79,7 \%)$. Dibanding responden yang tidak memiliki perilaku pencegahan yang baik yaitu sebanyak 7 responden $(9,5 \%)$. Sedangkan dari 8 responden $(10,8 \%)$ yang kurang mendapatkan dukungan dari petugas kesehatan, lebih banyak yang tidak memiliki perilaku pencegahan HIV/AIDS yang tidak baik yaitu sebanyak 7 responden $(9,5 \%)$. Dibanding responden yang memiliki perilaku pencegahan yang baik yaitu hanyak 1 responden $(1,4 \%)$. Sehingga hasil penelitian di atas menunjukkan bahwa responden yang mendapatkan dukungan dari petugas kesehatan memiliki perilaku pencegahan HIV/AIDS yang baik dibandingkan responden yang kurang mendapatkan dukungan dari petugas kesehatan. Hasil analisis menggunakan uji Chi-Square yang dilakukan terhadap faktor-faktor yang berhubungan dengan perilaku pencegahan HIV/AIDS pada kelompok LSL di Kota Palu, didapatkan hasil $p=0,000(a<0,05)$ sehingga Ho ditolak, artinya bahwa ada hubungan dukungan petugas kesehatan dengan perilaku pencegahan HIV/AIDS pada kelompok LSL di Kota Palu.

Penelitian yang sejalan dilakukan di Kota Jambi, yang menyatakan terdapat hubungan yang signifikan antara peran petugas kesehatan dengan perilaku pencegahan penularan HIV/AIDS pada GWL dalam memanfaatkan layanan konseling dan tes HIV, dengan nilai uji statistic $p$-value 0,000 $(\alpha<0,05)$. Hasil analisis juga menunjukkan nilai Odds Rasio sebesar 11.755 yang berarti bahwa GWL yang berpendapat peran petugas VCT kurang baik terhadap layanan konseling dan tes HIV tidak akan memanfaatkan layanan konseling dan tes HIVsebesar 12 kali dibandingkan GWL yang berpendapat peran petugas VCT baik. 


\section{Kesimpulan}

Berdasarkan hasil penelitian dan pembahasan, maka didapatkan kesimpulan sebagai berikut:

1. Ada hubungan pengetahuan dengan perilaku pencegahan HIV/AIDS pada kelompok LSL di Kota Palu.

2. Ada hubungan sikap dengan perilaku pencegahan HIV/AIDS pada kelompok LSL di Kota Palu dengan nilai.

3. Ada hubungan dukungan petugas kesehatan dengan perilaku pencegahan HIV/AIDS pada kelompok LSL di Kota Palu dengan nilai.

\section{Saran}

Sehubungan dengan hasil penelitian di atas, maka diharapkan agar peneliti selanjutnya bisa mengembangkan penelitian ini dengan memperbanyak jumlah sampel penelitian, jenis desain penelitian dan variabel yang berbeda untuk lebih mengetahui faktor lain yang berhubungan dengan perilaku pencegahan HIV/AIDS seperti perilaku seksual, akses informasi, dukungan sesama LSL, persepsi kerentanan, persepsi keseriusan dan persepsi hambatan.

\section{Daftar Pustaka}

1. Adeniran. 2017. Palliative Approach towards Managing HIV / AIDS Pandemic. International Journal of Health Medical Information. No. 2, Vol.3, Hal. 36-42.

2. Permenkes RI. 2019. Peraturan Menteri Kesehatan Republik Indonesia No. 4 Tahun 2019 Tentang Standar Teknis Pemenuhan Mutu Pelayanan Dasar Pada Standar Pelayanan Minimal Bidang Kesehatan.

3. UNAIDS. 2019. Global HIV and AIDS statistics. Vol. 1, Hal.1-6.

4. Sumampouw YB, Rampengan NH, Mantik MFJ. 2020. Profil HIV/AIDS di Bagian Ilmu Kesehatan Anak RSUP Prof. Dr. R.D. Kandou Manado Periode Januari 2009 sampai dengan Desember 2018. e-CliniC. No.1, Vol. 8, Hal. 109-14.

5. WHO. 2018 Monitoring Health for the SDG's (Sustainable Development Goals). World Health Statistics. Vol. 10, Hal. 1-85.

6. Sukiani, Aditya. 2020. Persepsi Orang Dengan HIV/AIDS (ODHA) Terhadap Perlakuan Keluarga Hindu dan sekitarnya. Bahasa dan Budaya. No.1, Vol. 4, Hal. 66-73.

7. SIHA. 2017. Situasi Umum HIV/AIDS dan Tes HIV. 2017. Hal. 2-10.

8. Dinkes Provinsi Sulteng. 2019. Profil Kesehatan Provinsi Sulawesi Tengah Tahun.

9. Dinkes Kota Palu. 2019. Profil Dinas Kesehatan Kota Palu Tahun 2019. Vol. 53.

10. Giano Z, et al. 2019. Factors Associated with Condom use Among a Sample of Men who have Sex with Men (MSM) Residing in Rural Oklahoma. Journal of Homosexualitty. Hal.1-21.

11. Cowan SA, Haff J. 2006. HIV and Risk Behaviour among Men who have Sex with Men in Denmark-the 2006 Sex Life Survey. Eurosurveillance. No. 48, Vol.13, Hal. 190.

12. Iriswati, Irawati. 2019. Buku Ajar Antropologi Kesehatan dalam Keperawatan. Deepublish. https://books.google.co.id/books?id=Ln-QDwAAQBAJ

13. Listina F, Baharza S nandar. 2020. Hubungan Pengetahuan dan Sikap LSL Terhadap Upaya Pencegahan HIV \& AIDS di Pusmkesmas Simpur Kota Bandar Lampung. Malahayati Nurs. No. 1, Vol. 2, Hal. 151-9.

14. Wawan A, Dewi M. 2010. Teori dan Pengukuran Pengetahuan, Sikap dan Perilaku Manusia. Yogyakarta.

15. Rahmadhani DY. 2018. Hubungan Pengetahuan tentang HIV/AIDS, Sikap dan Peran Petugas Kesehatan dalam Pemanfaatan Layanan Konseling dan Test HIV/AIDS pada GWL (Gay, 
Waria, Lelaki Seks Lelaki) di LSM MWGJ Kota Jambi. Akademika Baiturrahim. No.1, Vol. 7, Hal. 55-61.

16. Nasronudin. 2020. HIV \& AIDS Pendekatan Biologi Molekuler Klinis \& Sosial Ed 2. Airlangga University. Available from: https://books.google.co.id/books?id=WG_IDwAAQBAJ

17. Donsu JDT. 2017. Metodologi Penelitian Keperawatan. Yogyakarta : Pustakabarupress.

18. Nurmala I. 2020. Promosi Kesehatan. Airlangga University Press. Available from: https://books.google.co.id/books?id=SGvIDwAAQBAJ

19. Laksana B, Demartoto A. 2017. Knowledge, Attitude, Sexual Behavior, Family Support, and Their Associations with HIV/AIDS Status in Housewives. Epidemiology and Public Health. No. 2, Vol. 2, Hal. 154-63.

20. Wardhani PK, Shaluhiyah Z, Demartoto A. 2015. Perilaku Penggunaan Kondom dan Pelicin pada LSL di Kota Surakarta. Promosi Kesehat Indonesia. No.1, Vol.10, Hal.89-101.

21. Olusola IA, et al. 2015. Sexual Behaviour, HIV/STI Prevention Knowledge, and Utilization of VCT among The Residents in Sagamu Metropolis of Ogun State, Nigeria. International Journal of Prevention and Treatment Sientific \& Academic Publishing. No.1, Vol.4, Hal.8-13.

22. Wagenaar BH, Sullivan PS, Stephenson R. 2012. HIV Knowledge and Associated Factors among Internet using Men Who have Sex with Men (MSM) in South Africa and the United States. PLoS One. No.3, Vol.7.

23. Muntean N, Kereta W, Mitchell KR. 2015. Addressing the Sexual and Reproductive Health Needs of Young People in Ethiopia: an Analysis of the Current Situation. African Journal Reproductive Health. No.3, Vol.19, Hal.87-99.

24. Bos AER, Onya H. 2015. Fear of Stigmatization as Barrier to Voluntary HIV Counselling and Testing in South Africa. East African Journal of Public Health. No.2, Vol.5. Hal. 49.

25. Deering KN, et al. 2011. A Dose-Response Relationship Between Exposure to a Large-Scale HIV Preventive Intervention and Consistent Condom ese with Different Sexual Partners Of Female Sex Workers in Southern India. BMC Public Health. No.S6, Vol.11, Hal. 1-14.

26. Ruan F, Fu G, Yan Y, Li Y, Shi Y, Luo L, et al. 2019. Inequities In Consistent Condom Use Among Sexually Experienced Undergraduates In Mainland China: Implications for planning interventions. BMC Public Health. No.1, Vol.19, Hal.1-12.

27. Notoatmodjo S. 2014. Kesehatan Masyarakat Ilmu dan seni. Rineka Cipta. Available from: https://books.google.co.id/books?id=ghFRNwAACAAJ

28. Azwar S. 2013. Sikap Manusia Teori dan Keyakinan. Pustaka Pelajar. Yogyakarta.

29. Maskuniawan, Azinar M. 2018. Faktor-Faktor yang Berhubungan Dengan Praktik Tes HIV Pada Waria Pekerja Seks di Kota Semarang. Health Education. No.1,Vol.25, Hal. 57-60.

30. Wardani EM, Setiawan AH, Bistara DN. 2020. Studi Perilaku Seks Menyimpang Terhadap Kejadian HIV Fase Laten pada Komunitas Lelaki Seks Lelaki (LSL) di LSM Kompeda Surabaya. Keperawatan dan Kesehat Masyarakat. No.1, Vol.9, Hal. 93-101.

31. Kapanda L, Jumbe V, Izugbara C, Muula AS. 2019. Healthcare Providers' Attitudes Towards Care for Men who have Sex with Men (MSM) in Malawi. BMC Health Services Research. No.1, Vol.19, Hal. 316.

32. Mujiati M, Pradono J. 2014. Faktor Persepsi dan Sikap Dalam Pemanfaatan Layanan Voluntary Counseling And Testing (VCT) oleh Kelompok Berisiko HIV/AIDS di Kota Bandung Tahun 2013. Kesehatan Reproduksi. No.1, Vol.5, Hal.49-57.

33. Som P, Bhattacherjee S, Guha R, Basu M, Datta S. 2015. A Study of Knowledge and Practice Among Nurses Regarding Care of Human Immunodeficiency Virus Positive Patients in Medical College and Hospitals of Kolkata, India. Annals of Nigerian Medicin. No.1, Vol.9, 
Hal.15.

34. Gyamerah AO, Taylor KD, Atuahene K, Anarfi JK, Fletcher M, Raymond HF, et al. 2020. Stigma, Discrimination, Violence, and HIV Testing among Men Who have Sex with Men in four Major Cities in Ghana. AIDS Care. Hal 1-9.

35. Zarei N, Joulaei H, Darabi E, Fararouei M. 2015. Stigmatized Attitude of Healthcare Providers: a Barrier for Delivering Health Services to HIV Positive Patients. International Journal of Community Based Nursing and Midwifery. No.4, Vol.3, Hal.292.

36. Ebrahimi F, Sindarreh S, Nasirian M. 2020. Attitudes and Practice of Health Care Workers about Human Immunodeficiency Virus in Isfahan, Iran. Iranian Journal of Nursing and Midwifery Research. No.2, Vol.25, Hal. 111. 